Diterima: 26/03/2021, Direview: 24/05/2021, Diterbitkan: 31/10/2021

\title{
PENGARUH NATRIUM BENZOAT DAN WAKTU PENYIMPANAN TERHADAP MUTU KIMIA DAN MIKROBIOLOGIS SELAI PALA (Myristica fragrans Houtt)
}

\section{Effect Of Sodium Benzoate And Storage Time For Quality Chemical dan Microbiology Of Nutmeg Jam (Myristica fragrans Houtt)}

\author{
Centhya Victorin Maitimu*
}

Program Studi Pendidikan Biologi - STKIP Gotong Royong Masohi

Jl. Trans Seram Belakang Negeri Haruru Kode Pos 97514 Masohi

*Penulis Korespondensi, Email: victorin.thya@gmail.com

\begin{abstract}
ABSTRAK
Penelitian ini bertujuan untuk menganalisis pengaruh natrium benzoat dan waktu penyimpanan terhadap mutu kimia dan mikrobiologi selai pala. Penelitian dilakukan secara acak lengkap dengan dua variabel yaitu natrium benzoat dan waktu penyimpanan dengan dua ulangan. Hasilnya menunjukkan bahwa konsentrasi natrium benzoat dapat mempertahankan kandungan vitamin $\mathrm{C}$ hingga penyimpanan 15 hari. Namun penambahan $250 \mathrm{mg}$ natrium benzoat pada penyimpanan 15 hari dapat mengawetkan selai pala dengan kandungan vitamin C $0.138 \mathrm{mg} / 100 \mathrm{~g}$ bahan, total asam $9.25 \mathrm{mg} / 100 \mathrm{~g}$ bahan dan nilai $\mathrm{pH}$ 2.00. Sedangkan penambahan natrium benzoat $750 \mathrm{mg}$ dapat mengawetkan selai pala hingga 60 hari ditunjukkan dengan jumlah koloni terendah $\left(25 \times 10^{-3} \mathrm{CFU} / \mathrm{ml}\right)$ yang memenuhi standar mutu Indonesia (SNI). Kesimpulannya, produksi selai pala dengan penambahan natrium benzoat layak untuk memperpanjang waktu penyimpanan.
\end{abstract}

Kata kunci: ALT, kandungan vitamin C, Natrium benzoat, Nilai $\mathrm{pH}$, Total asam, waktu penyimpanan

\section{ABSTRACT}

This study investigated the impact of sodium benzoate and storage time on quality chemical and microbiology of nutmeg jam. The experiment performed totally randomized plan by two variables, to be specific convergence of sodium benzoate and storage time with two repetitions. The result showed, the addition of sodium benzoate preserve vitamin $C$ content up to 15 days. However, addition of $250 \mathrm{mg}$ sodium benzoate at 15 days storage could preserve nutmeg jam by vitamin $C$ content of $0.138 \mathrm{mg} / 100 \mathrm{~g}$ ingredients, total acid 9.25 $\mathrm{mg} / 100 \mathrm{~g}$ ingredients and $\mathrm{pH}$ value 2.00. Meanwhile, addition of $750 \mathrm{mg}$ sodium benzoate could preserve nutmeg jam up to 60 days indicated by lowest to number of colonies $\left(25 \times 10^{-}\right.$ ${ }^{3} \mathrm{CFU} / \mathrm{ml}$ ) that comply with Indonesia standard of quality (SNI). In summary, production of nutmeg jam by adding sodium benzoate was feasible to prolong storage time.

Keywords: Sodium benzoate, storage time, vitamin c content, total acid, $\mathrm{pH}$ value, TPC

\section{PENDAHULUAN}

Tanaman pala (Myristica fragrans, Houtt) adalah salah satu jenis tanaman penyedap rasa yang mempunyai nilai ekonomis dan bermultiguna, dengan tingkat produksi diperkirakan 19.9 ribu ton setiap tahun (Nurdjanah, 2007). Maluku sebagai salah satu provinsi penghasil pala tidak banyak mendayagunakan pala hasil produksi jika dibandingkan dengan provinsi lainnya. Di beberapa sentra produksi di wilayah Maluku, daging buah pala seringkali terbuang percuma dibawah pohon setelah diambil biji dan fuli nya, tanpa diolah atau tidak dihiraukan 
oleh para petani. Kalaupun ada yang diolah, hanya sebagian kecil yang umumnya dibuat manisan. Hal ini disebabkan karena terbatasnya pengetahuan para petani tentang diversifikasi pangan olahan, padahal daging pala dapat dilakukan diversifikasi pangan sehingga menghasilkan produk inovatif bernilai ekonomis tinggi (Sipahelut, dkk, 2011). Dalam $100 \mathrm{~g}$ daging pala mengandung 42 kalori, $0.3 \%$ protein, $0.2 \%$ lemak, $10.9 \%$ pati, $29.5 \mathrm{UI}$ vitamin A, $22 \mathrm{mg}$ vitamin C, $32 \mathrm{mg}$ kalsium, $24 \mathrm{mg}$ fosfor, $1.5 \mathrm{mg}$ zat besi, dan $1.1 \%$ minyak atsiri (Nurdjanah, 2007). Karena daging pala adalah bagian yang terbesar dari hasil panen pala lainnya dan memiliki prospek yang baik sebagai bahan baku pengolahan maka salah satu cara pemanfaatan daging pala agar tidak menjadi limbah adalah dengan mengolah daging pala menjadi selai.

Selai adalah salah satu makanan semi-basah yang terkenal dan dinikmati oleh masyarakat umum dan merupakan produk alami yang disiapkan yang terbuat dari 45 bagian berat produk bagian tanah menurut berat gula, namun jumlah ini dapat diubah dengan aroma dan cita rasa yang ideal dan kemudian dikentalkan dengan cara dimasak. Selai pala memiliki rasa dan aroma tertentu yang didapat dari campuran eter 2-18\% yang berbau manis, misalnya miristisin, elemisin dan safrol yang terkandung dalam pala. Pembuatan selai pala, selain dapat memberikan nilai tambah daging pala juga membawa manfaat yang cukup besar, hal ini dikarenakan selai selanjutnya dapat disimpan dalam kurun waktu yang relatif lama dengan menambahkan zat aditif natrium benzoat (Sherylya et al., 2019).

Penambahan zat aditif natrium benzoat pada selai pala berfungsi untuk menjaga produk dari kerusakan mikroorganisme dengan menekan laju pembusukan dan fermentasi sehingga selai pala dapat bertahan cukup lama selama masa penyimpanan. Sebagaimana yang dijelaskan oleh Rorong dan Wilar (2019) bahwa dengan menambahkan zat aditif (natrium benzoat) dalam suatu produk pangan dapat memperpanjang umur simpan dan meningkatkan kualitas suatu pangan. Untuk bahan olahan yang bersifat asam misalnya selai pala, dosis natrium benzoat maksimum adalah $1000 \mathrm{mg} / \mathrm{kg}$ bahan (SNI 01-0222-1995, 1995).

Kombinasi antara natrium benzoat dan waktu penyimpanan merupakan indikator penentu mutu selai pala yang dihasilkan baik secara kimia maupun mikrobiologi, sehingga penting untuk dilakukan penelitian tentang pengaruh natrium benzoat dan waktu penyimpanan terhadap mutu kimia (kandungan vitamin $\mathrm{C}$, total asam, nilai $\mathrm{pH}$ ) dan mikrobiologi (angka lempeng total $(\mathrm{ALT})$ ) selai pala.

\section{BAHAN DAN METODE}

\section{Bahan}

Penggunaan bahan terdiri dari daging pala tanpa kulit sebanyak, gula pasir, natrium benzoat, vanili, air matang dan bahan-bahan analisis meliputi asam askorbat (Analytical Grade, Merck, Darmstadt, Germany), iodium $0.01 \mathrm{~N}$ (Titripur, Reag. Ph Eur) larutan pati 1\% (CP PUDAK), larutan Natrium Hidroksida $0.01 \mathrm{~N}(\mathrm{NaOH}$, Merck, Darmstadt, Germany), kertas lakmus (Merck Universal, CV. Gabedo Jaya, Balikpapan), kertas saring (Whatman Filter Paper), Plate Count Agar (Merck, Darmstadt Germany), larutan Butterfiel's Phosphate Buffered-BPB (Merck, Darmstadt Germany) dan air suling (aquades).

\section{Alat}

Peralatan terdiri dari pisau, baskom, wajan, panci, kompor, blender (PCS 00805.04, Miyako, Indonesia), pengaduk, timbangan biasa (Kitchen scale Q2-8016, Indonesia), timbangan analitik (ABS 220-4, Kern, Germany), labu takar, gelas ukur, erlenmeyer, corong glass, pipet volum, pipet tetes, alat titrasi, pH meter (F-20 FiveEasy Mettler Toledo, USA), cawan petri, Hand Tally Counter (Funke Gerber, Germany), dan inkubator (IN55, Memmert Germany).

\section{Desain Penelitian}

Penelitian dilakukan secara acak lengkap dengan dua variabel yaitu natrium benzoat dan waktu penyimpanan dengan dua ulangan. Variabel pertama: konsentrasi natrium benzoat 
empat taraf yaitu A0 (tanpa natrium benzoat), A1 (250 mg/kg selai), A2 (500 mg/ kg selai), A3 (750 mg/ kg selai). Variabel kedua: waktu penyimpanan dengan lima taraf yaitu: L0 (0 hari), L1 (15 hari), L2 (30 hari), L3 (45 hari), L4 (60 hari), sehingga total satuan percobaan adalah 4 $\times 5 \times 2=40$.

\section{Tahapan Penelitian}

Tahapan penelitian yang dilaksanakan yaitu : (1). Prosedur pembuatan selai pala, (2). Analisis kandungan kimia selai pala yang meliputi kandungan vitamin $\mathrm{C}$, total asam, nilai $\mathrm{pH}$, serta analisis mikrobiologis meliputi Angka Lempeng Total (ALT) pada hari ke 60 penyimpanan.

\section{Prosedur Pembuatan Selai}

Buah pala setelah diambil biji dan fulinya, selanjutnya dikupas dan dibuang selaput yang terdapat pada bagian dalam buah. Selanjutnya daging buah pala yang sudah dikupas, dicuci sampai bersih atau direndam dengan menggunakan air yang diberi sedikit garam. Daging buah pala yang sudah dicuci bersih, kemudian direbus sampai daging buah menjadi lunak untuk mempermudah proses penghancuran dan selanjutnya daging buah pala yang sudah direbus tersebut diblender. Setelah diblender, hancuran daging buah pala yang berupa bubur buah dimasukkan dalam wajan, tambahkan gula pasir (perbandingan 1:1) serta vanili sebagai penambah aroma dan dimasak sampai terbentuknya selai. Selai yang sudah masak, selanjutnya ditimbang masing-masing sebanyak $1 \mathrm{~kg}$ sesuai dengan perlakuan natrium benzoat dan lama penyimpanan. Setelah proses penimbangan, dalam keadaan panas selai dicampurkan dengan pengawet natrium benzoat sesuai perlakuan $(0,250,500$ dan $750 \mathrm{mg})$ per kg selai pala. Selanjutnya selai pala dikemas dalam kemasan gelas atau botol yang terlebih dahulu sudah disterilkan dan harus kering pada saat akan dipergunakan, sesuai dengan interaksi perlakuan dengan pengulangan sebanyak dua kali. Setelah dikemas, selai siap untuk disimpan pada tempat yang bersih dan aman selama waktu penyimpanan, yang selanjutnya dianalisis kandungan vitamin $\mathrm{C}$, total asam, nilai $\mathrm{pH}$ dan angka lempeng total $(\mathrm{ALT})$ pada 60 hari penyimpanan.

\section{Evaluasi \\ Penentuan Kadungan Vitamin C (MetodeTitrasi)}

Penentuan kandungan vitamin $\mathrm{C}$ metode titrasi dilakukan berdasarkan metode yang diajukan oleh Sudarmadji et al., (2007): timbang sebanyak $100 \mathrm{~g}$ sampel (selai pala), diencerkan sampai dengan $250 \mathrm{ml}$. Titrasi dengan larutan iodium $0.01 \mathrm{~N}$ dan pati. Perhitungan kandungan vitamin $\mathrm{C}$ dapat dihitung dengan rumus :

$$
A=\frac{\text { ml lodium } 0.01 \mathrm{~N} \times 0.88}{\mathrm{~g} \text { sampel }} \times 100
$$

Dimana : $\quad A=$ Asam askorbat $(\mathrm{mg} / 100 \mathrm{~g}$ bahan)

$1 \mathrm{ml} \operatorname{lod} 0.01 \mathrm{~N} \quad \mathrm{H} \quad 0.88 \mathrm{mg}$ asam askorbat

\section{Penentuan Total Asam (MetodeTitrasi)}

Penentuan total asam dilakukan berdasarkan metode yang diajukan oleh Sudarmadji, $d k k$ (2007): timbang sebanyak $100 \mathrm{~g}$ sampel (selai pala), lalu masukkan pada labu takar 250 $\mathrm{ml}$, kemudian lakukan pengenceran sampai tanda batas, selanjutnya disaring. Ukur sebanyak $25 \mathrm{ml}$ filtrat masukkan dalam gelas erlenmeyer, tambahkan indikator phenolphtalein (pp) \pm 2 sampai 3 tetes, titrasi dengan larutan $\mathrm{NaOH} 0.01 \mathrm{~N}$. Untuk mengetahui total asam selai pala dapat dihitung dengan rumus :

$$
\mathrm{TA}=\frac{\mathrm{V} \times \mathrm{N} \times 100}{\text { gr sampel }}
$$


Dimana :

$\mathrm{TA}=$ Total asam (mg/100g bahan), $\mathrm{V}=\mathrm{ml} \mathrm{NaOH}, \mathrm{N}=$ Normalitas $\mathrm{NaOH}$

\section{Penentuan pH}

Penentuan pH dilakukan berdasarkan SNI 01-2891-1992: timbang $10 \mathrm{~g}$ sampel (selai), kemudian tambahkan $20 \mathrm{ml}$ aquades, campur hingga larutan homogen. Ukur nilai pH dengan $\mathrm{pH}$ meter yang sudah dikalibrasi menggunakan larutan buffer $\mathrm{pH}$ standart. Nilai yang terbaca pada skala $\mathrm{pH}$ meter yang ditunjukkan jarum merupakan nilai $\mathrm{pH}$ yang dihitung.

\section{Penentuan ALT (Angka Lempeng Total)}

Penentuan ALT (Angka Lempeng Total) dilakukan dengan SNI-01-2339-1991/M13: dalam kondisi steril ukur $25 \mathrm{~g}$ sampel (selai), kemudian masukan dalam blender steril. Tambahkan larutan BPB (Butterfield's Phosphat Buffered) steril $225 \mathrm{ml}$ lalu aduk selama \pm 1 hingga 2 menit. Pindahkan $1 \mathrm{ml}$ suspensi dengan menggunakan pipet steril, lanjutkan dengan menambahkan larutan BPB guna mendapatkan pengenceran $10^{-2}$. Siapkan pengenceran $10^{-}$ ${ }^{3}$ kemudian ambil $1 \mathrm{ml}$ suspensi pada pengenceran $10^{-2}$ dan pipet ke $10^{-3}$ lalu tambahkan 9 $\mathrm{ml}$ larutan BPB ke dalamnya. Demikian pula untuk pengeceran selanjutnya $\left(10^{-4}, 10^{-5}, \ldots,\right)$ lakukan dengan prosedur yang sama sesuai kebutuhan. Pipet $1 \mathrm{ml}$ dari tiap pengenceran, masukkan pada petri dish steril secara duplo untuk setiap pengencerannya. Tuang $12-15 \mathrm{ml}$ PCA ( telah didinginkan pada suhu $44-46^{\circ} \mathrm{C}$ ) ke setiap petri dish yang telah diberikan larutan suspensi. Agar larutan suspensi dan PCA tercampur merata, putar petri dish ke arah depan dan belakang. Selanjutnya diinkubasi \pm 48 jam ( 2 hari) dalam inkubator bersuhu $\pm 35^{\circ} \mathrm{C}$. perhitungan total koloni dilakukan pada tiap cawan petri yang berisi 25-250 koloni dengan alat penghitung koloni (Hand Tally Counter).

\section{Analisis Statistik}

Analisis statistik menggunakan analisis sidik ragam, dan diteruskan dengan uji pembandingan rata-rata taraf perlakuan dan kombinasi taraf perlakuan menggunakan DMRT (Duncan's Multiple Range Test) pada taraf $0.05 \%$.

\section{Kadungan Vitamin $C$}

\section{HASIL DAN PEMBAHASAN}

Vitamin C merupakan nutrient pencegah kanker (antioksidan) yang sangat dibutuhkan oleh tubuh. Antioksidan sangat berperan penting dalam menjaga tubuh yang sehat serta mencegah radikal bebas. Vitamin C (asam askorbat) adalah suplemen pembentuk kolagen, yang dapat memperbaiki kulit, gigi dan tulang yang biasanya diperoleh dari bahan alam, salah satunya terdapat pada bahan alam sekitar seperti pala. Sunanto, (1993), merekomendasikan bahwa kadar vitamin $\mathrm{C}$ daging pala adalah $22 \mathrm{mg} / 100 \mathrm{~g}$ daging buah. Kandungan vitamin $\mathrm{C}$ selai pala perlakuan natrium benzoat dan waktu penyimpanan antara 0.085 sampai $0.138 \mathrm{mg} / 100 \mathrm{~g}$ bahan. Hasil penelitian membuktikan bahwa interaksi perlakuan natrium benzoat dan waktu penyimpanan berpengaruh nyata pada kandungan vitamin $\mathrm{C}$ selai pala. Ini dikarenakan vitamin $C$ yang secara alami dalam buah mengalami perubahan setelah penanganan. Vitamin $\mathrm{C}$ adalah senyawa yang memiliki sifat terlarut dalam air, bersifat asam serta memiliki sifat pereduksi kuat sehingga mudah teroksidasi oleh beberapa jenis katalis logam seperti $\mathrm{Cu}$ dan Ag (Polnaya dkk, 2009). Kandungan vitamin C yang paling tinggi $(0.137 \mathrm{mg} / 100 \mathrm{~g}$ bahan) ditunjukkan oleh interaksi perlakuan natrium benzoat $750 \mathrm{mg}$ pada hari ke-15 penyimpanan, sedangkan kandungan vitamin $C$ paling sedikit $(0.085 \mathrm{mg} / 100 \mathrm{~g}$ bahan) ditunjukkan oleh interaksi perlakuan natrium benzoat $500 \mathrm{mg}$ pada hari ke-60 penyimpanan. Jika dibandingkan dengan kandungan vitamin $C$ daging pala, maka kandungan vitamin $C$ selai pala sehubungan dengan interaksi perlakuan natrium benzoat dan lama penyimpanan berkurang atau mengalami penurunan, hal ini bisa jadi karena vitamin $\mathrm{C}$ yang terkandung didalam selai pala sangat mudah rusak dan larut dalam air. 
Gaman dan Sherrington (1994) dalam Polnaya dkk (2009), mengemukakan jika vitamin C (asam askorbat) memiliki sifat mudah rusak diantara semua vitamin lainnya, mudah larut dalam air dan teroksidasi secara efektif. Oksidasi yang dialami oleh asam askorbat sangat cepat ketika dalam kondisi alkalis, suhu yang tinggi, terpapar sinar matahari dan logam rendah. Rusaknya vitamin $\mathrm{C}$ juga diidentifikasi dengan aktivitas enzim askrobat oksidase, hal ini sesuai pendapat Oktoviana, dkk (2012), bahwa asam askorbat secara efektif mudah teroksidasi secara kimia menghasilkan asam L-dehidroskorbat sehingga bersifat tidak stabil berubah menjadi asam L-diketogulonat, dan asam ini tidak memiliki sifat vitamin $\mathrm{C}$. Penurunan kandungan vitamin $\mathrm{C}$, juga dikarenakan oleh proses pemasakan dan penyimpanan yang dapat mengakibatkan vitamin C rusak dan hilang (Naidu, 2003). Ditambahkan pula oleh Mukaromah et al, (2010), bahwa vitamin $\mathrm{C}$ bahwa semakin rendah kandungan vitamin $\mathrm{C}$ yang terkandung dalam selai pala kemudian dipanaskan, maka semakin sedikit kandungan vitamin $\mathrm{C}$ yang dihasilkan.

Tabel 1. Kandungan Vitamin C Selai Pala Pengaruh Natrium Benzoat dan Waktu Penyimpanan

\begin{tabular}{|c|c|c|c|c|c|}
\hline \multirow[t]{2}{*}{$\begin{array}{c}\text { Natrium } \\
\text { Benzoat } \\
(\mathrm{mg})\end{array}$} & \multicolumn{5}{|c|}{$\begin{array}{l}\text { Waktu Penyimpanan } \\
\text { (hari) }\end{array}$} \\
\hline & LO (0) & L1 (15) & L2 (30) & L3 (45) & L4 (60) \\
\hline $\mathrm{AO}(0)$ & $\begin{array}{l}0.128^{b c} \\
\pm 0.0\end{array}$ & $\begin{array}{l}0.124^{\text {cd }} \\
\pm 0.00025\end{array}$ & $\begin{aligned} & 0.107^{f} \\
\pm & 0.000081\end{aligned}$ & $\begin{array}{l}0.097^{9} \\
\pm 0.00016\end{array}$ & $\begin{array}{l}0.090^{\mathrm{h}} \\
\pm 0.0001\end{array}$ \\
\hline A1 (250) & $\begin{array}{l}0.129^{\mathrm{bc}} \\
\pm 0.0\end{array}$ & $\begin{array}{l}0.138^{\mathrm{a}} \\
\pm 0.0\end{array}$ & $\begin{array}{l}0.120^{\mathrm{d}} \\
\pm 0.0\end{array}$ & $\begin{array}{l}0.104^{\dagger} \pm \\
0.000064\end{array}$ & $\begin{array}{l}0.096^{9} \\
\pm 0.000001\end{array}$ \\
\hline$A 2(500)$ & $0.132^{b} \pm 0.0$ & $\begin{array}{l}0.131^{\mathrm{b}} \\
\pm \\
0.000016\end{array}$ & $\begin{aligned} & 0.122^{\mathrm{d}} \\
\pm & 0.000004\end{aligned}$ & $\begin{array}{l}0.098^{9} \\
\pm 0.000001\end{array}$ & $\begin{aligned} & 0.085^{\mathrm{h}} \\
\pm & 0.000001\end{aligned}$ \\
\hline A3(750) & $\begin{array}{c}0.131^{b} \\
\pm 0.0\end{array}$ & $\begin{array}{c}0.137^{\mathrm{a}} \\
\pm 0.000001\end{array}$ & $\begin{array}{c}0.130^{\mathrm{a}} \\
\pm 0.000009\end{array}$ & $\begin{array}{c}0.113^{\mathrm{e}} \\
\pm 0.000004\end{array}$ & $\begin{array}{c}0.089^{\mathrm{h}} \pm \\
0.000001\end{array}$ \\
\hline
\end{tabular}

Keterangan : Angka dengan huruf sama artinya tidak berbeda nyata pada DMRT $0.05 \%$.

Zentimer, (2007) berdasarkan penelitiannya memberikan penjelasan bahwa tinggi rendahnya kandungan vitamin $\mathrm{C}$ sangat dipengaruhi oleh natrium benzoat. Jika natrium benzoat yang ditambahkan semakin tinggi, maka aktivitas natrium benzoat dalam mempengaruhi aktivitas enzim pun semakin tinggi, sehingga proses oksidasi vitamin $\mathrm{C}$ terhambat yang mengakibatkan kandungan vitamin $\mathrm{C}$ menjadi stabil, hal ini terlihat pada kandungan vitamin $\mathrm{C}$ tertinggi yang ditunjukkan oleh perlakuan natrium benzoat $750 \mathrm{mg}$ pada penyimpanan hari ke-15 $(0.137 \mathrm{mg} / 100 \mathrm{~g}$ bahan). Hal ini dipertegas dengan hasil penelitian Sumanik, dkk (2017), bahwa natrium benzoat dan waktu penyimpanan berpengaruh pada penurunan kandungan vitamin $\mathrm{C}$ karena selai pala yang dihasilkan memiliki pH asam maka vitamin $C$ lebih stabil. Dengan demikian antara perlakuan $A_{3} L_{1}$ dengan perlakuan $A_{1} L_{1}, A_{2} L_{0}$, $A_{2} L_{1}$, dan $A_{3} L_{0}$ kandungan vitamin C-nya tidak berbeda jauh, dengan demikian kandungan vitamin $C$ selai pala akan terhambat penurunannya selama penyimpanan dengan adanya pemberian pengawet natrium benzoat. Selain itu juga penambahan gula dalam proses pembuatan selai pala sangat berpengaruh terhadap kandungan Vitamin $\mathrm{C}$ karena dapat mempercepat lajunya proses degradasi vitamin $\mathrm{C}$.

\section{Total Asam}

Total asam didefinisikan sebagai jumlah asam dalam bahan misalnya asam malat, folat, sitrat dan askorbat (Winarno, 2004). Hasil penelitian mengindikasikan bahwa interaksi perlakuan natrium benzoat dan waktu penyimpanan berpengaruh nyata pada total asam selai pala. Jika dibandingkan dengan total asam buah pala segar (5.89\%) maka total asam selai pala perlakuan natrium benzoat dan waktu penyimpanan adalah 4.38 sampai $9.25 \mathrm{mg} / 100 \mathrm{~g}$ bahan, cenderung mengalami peningkatan, hal ini disebabkan karena perlakuan natrium benzoat pada selai pala. Kadar total asam tertinggi $(9.25 \mathrm{mg} / 100 \mathrm{~g}$ bahan) ditunjukkan oleh interaksi perlakuan natrium benzoat $500 \mathrm{~g}$ pada hari ke-15 penyimpanan. 
Berdasarkan hasil penelitian terlihat bahwa terjadinya penurunan kandungan total asam selai pala selama penyimpanan. Menurut Farikha, dkk (2013) bahwa terjadinya penurunan kandungan total asam erat hubungannya dengan penguraian asam-asam organik misalnya asam sitrat, askorbat, malat dan folat yang terdapat dalam buah pala. Apabila proses penguraian asam organik berlangsung cepat maka kandungan total asam akan mengalami penurunan selama penyimpanan (Sumanik dkk, 2017). Hasil penelitian juga menunjukkan bahwa tingkat keasaman atau total asam dapat dihambat penurunannya dengan adanya perlakuan natrium benzoat dan waktu penyimpanan. Ini berarti dengan bertambahnya natrium benzoat dan waktu penyimpanan maka kandungan total asam selai pala akan mengalami penurunan, hal ini terlihat pada hari ke 60 penyimpanan total asam selai buah pala mengalami penurunan.

Tabel 2. Total Asam Selai Pala Pengaruh Perlakuan Natrium Benzoat dan Waktu Penyimpanan

\begin{tabular}{|c|c|c|c|c|c|}
\hline \multirow[t]{2}{*}{$\begin{array}{l}\text { Natrium Benzoat } \\
\text { (mg) }\end{array}$} & \multicolumn{5}{|c|}{$\begin{array}{l}\text { Waktu Penyimpanan } \\
\text { (hari) }\end{array}$} \\
\hline & L0 (0) & L1 (15) & L2 (30) & L3 (45) & L4 (60) \\
\hline \multirow[t]{2}{*}{$A 0(0)$} & $4.48^{\mathrm{e}}$ & $8.82^{\mathrm{ab}}$ & $6.45^{c}$ & $4.53^{\mathrm{e}}$ & $4.42^{\mathrm{e}}$ \\
\hline & \pm 0.0 & \pm 0.58 & \pm 0.14 & \pm 0.15 & \pm 0.0 \\
\hline \multirow{2}{*}{ A1 (250) } & $4.48^{\mathrm{e}}$ & $8.57^{b}$ & $6.20^{c}$ & $4.78^{e}$ & $4.38^{e}$ \\
\hline & \pm 0.01 & \pm 0.032 & \pm 0.06 & \pm 0.19 & \pm 0.032 \\
\hline \multirow[t]{2}{*}{ A2 (500) } & $4.41^{\mathrm{e}}$ & $9.25^{\mathrm{a}}$ & $6.04^{\mathrm{cd}}$ & $4.85^{\mathrm{e}}$ & $4.39^{\mathrm{e}}$ \\
\hline & \pm 0.0 & \pm 0.14 & \pm 0.0004 & \pm 0.09 & \pm 0.0036 \\
\hline \multirow[t]{2}{*}{$A 3(750)$} & $4.57^{\mathrm{e}}$ & $8.36^{b}$ & $5.63^{d}$ & $4.74^{\mathrm{e}}$ & $4.51^{\mathrm{e}}$ \\
\hline & \pm 0.0 & \pm 0.0841 & \pm 0.063 & \pm 0.35 & \pm 0.02 \\
\hline
\end{tabular}

Keterangan : Angka dengan huruf sama artinya tidak berbeda nyata pada DMRT $0.05 \%$.

Hasil penelitian membuktikan bahwa penyimpanan hari ke-15 kandungan total asamnya tinggi yaitu 8.75 , hal ini disebabkan karena pada penyimpanan hari ke-15 telah terjadi proses fermentasi secara spontan yang menghasilkan asam sehingga menyebabkan peningkatan kandungan total asam selai pala. Fermentasi spontan menurut Suprihatin, (2010) merupakan proses fermentasi yang terjadi karena adanya bantuan mikroorganisme selama prosesnya. Peningkatan kandungan total asam juga diduga karena lambatnya proses penguraian asamasam organik sebagai akibat dari penurunan konsentrasi udara karena adanya pengaruh kemasan yang kedap udara. Kenaikan total asam juga diduga karena penguraian ion $\mathrm{H}^{+}$dari natrium benzoat dalam bentuk garam yang berasal dari asam benzoat yang terbentuk saat dilarutkan dalam air. Molekul asam benzoat kemudian akan teroksidasi sehingga menghasilkan ion $\mathrm{H}^{+}$. Pada penyimpanan hari ke-30 memperlihatkan total asam menurun yaitu 6.08. Hal ini kemungkinan disebabkan karena asam yang dihasilkan dari proses fermentasi sudah berada dalam keadaan jenuh atau pekat atau berada pada batas maksimal, dan kemungkinan bereaksi dengan senyawa lain atau teroksidasi sehingga tidak terdeteksi sebagai asam sehingga pada penyimpanan hari ke-30, 45 dan 60 kandungan total asam selai pala mengalami penurunan (Salfauqi, dkk, 2018).

\section{Nilai $\mathrm{pH}$}

Nilai $\mathrm{pH}$ daging buah pala segar adalah sebesar 3.35, sedangkan $\mathrm{pH}$ yang dibutuhkan dalam proses pembuatan selai berkisar antara 3.10-3.46. Rata-rata nilai $\mathrm{pH}$ selai pala interaksi perlakuan natrium benzoat dan waktu penyimpanan adalah 1.90-3.40. Berdasarkan hasil penelitian, interaksi perlakuan natrium benzoat dan waktu penyimpanan tidak berpengaruh nyata, sedangkan perlakuan faktor tunggal masing-masing natrium benzoat dan waktu penyimpanan berpengaruh nyata pada nilai $\mathrm{pH}$. Hal ini mengindikasikan bahwa perlakuan faktor tunggal secara mandiri lebih mempengaruhi nilai $\mathrm{pH}$ selai pala bila dibandingkan dengan interaksi perlakuan. 
Tabel 3. Nilai pH Selai Pala Pengaruh Perlakuan Natrium Benzoat dan Waktu Penyimpanan

\begin{tabular}{|c|c|c|c|c|c|}
\hline \multirow[t]{2}{*}{$\begin{array}{c}\text { Natrium Benzoat } \\
(\mathrm{mg})\end{array}$} & \multicolumn{5}{|c|}{$\begin{array}{l}\text { Waktu Penyimpanan } \\
\text { (hari) }\end{array}$} \\
\hline & LO (0) & L1 (15) & L2 (30) & L3 (45) & L4 (60) \\
\hline $\mathrm{A} 0(0)$ & $\begin{array}{r}1.90 \\
\pm 0.0\end{array}$ & $\begin{array}{l}2.00 \\
\pm 0.0\end{array}$ & $\begin{array}{r}2.60 \\
\pm 0.0\end{array}$ & $\begin{array}{r}2.80 \\
\pm 0.2\end{array}$ & $\begin{array}{r}3.35 \\
\pm 0.0\end{array}$ \\
\hline A1 (250) & $\begin{array}{r}1.90 \\
\pm 0.0\end{array}$ & $\begin{array}{l}2.00 \\
\pm 0.0\end{array}$ & $\begin{array}{l}2.60 \\
\pm 0.0\end{array}$ & $\begin{array}{l}2.80 \\
\pm 0.0\end{array}$ & $\begin{array}{l}3.40 \\
\pm 0.0\end{array}$ \\
\hline A2 (500) & $\begin{array}{r}2.00 \\
\pm 0.0\end{array}$ & $\begin{array}{l}2.10 \\
\pm 0.0\end{array}$ & $\begin{array}{r}2.55 \\
\pm 0.2\end{array}$ & $\begin{array}{l}2.85 \\
\pm 0.2\end{array}$ & $\begin{array}{l}3.40 \\
\pm 0.0\end{array}$ \\
\hline A3 (750) & $\begin{array}{l}2.00 \\
\pm 0.0\end{array}$ & $\begin{array}{l}2.10 \\
\pm 0.0\end{array}$ & $\begin{array}{l}2.60 \\
\pm 0.0\end{array}$ & $\begin{array}{l}2.85 \\
\pm 0.2\end{array}$ & $\begin{array}{l}3.40 \\
\pm 0.0\end{array}$ \\
\hline
\end{tabular}

Keterangan : Angka dengan huruf sama artinya tidak berbeda nyata pada DMRT $0.05 \%$.

Untuk perlakuan natrium benzoat terlihat bahwa tanpa perlakuan natrium benzoat $\left(A_{0}\right)$ memiliki nilai $\mathrm{pH}$ terendah yaitu 2.52 dan berpengaruh sangat nyata bila dibandingkan dengan perlakuan lainnya. Nilai pH tertinggi pada perlakuan natrium benzoat $750 \mathrm{mg}\left(\mathrm{A}_{3}\right)$ yaitu 2.59 dan tidak berbeda nyata dengan perlakuan $250 \mathrm{mg}\left(A_{1}\right)$ dan perlakuan natrium benzoat 500 $\mathrm{mg}\left(\mathrm{A}_{2}\right)$. Hal ini oleh Salfauqi, dkk (2018) dijelaskan bahwa meningkatnya nilai pH ditentukan oleh bahan pengawet natrium benzoat yang bersifat asam yang terurai secara aktif dalam suatu produk bahan makanan yang diawetkan, karena apabila nilai $\mathrm{pH}$-nya tinggi maka daya awet natrium benzoat akan berkurang. Dikatakan pula oleh Salfauqi, dkk (2018) bahwa natrium benzoat sangat efektif digunakan dengan kisaran nilai pH 2.5 sampai 4.0. Karena apabila nilai pH-nya tinggi maka daya awet natrium benzoat akan berkurang.

Tabel 4. Nilai pH Selai Pala Pengaruh Perlakuan Natrium Benzoat

\begin{tabular}{cc}
\hline Natrium Benzoat $(\mathbf{m g})$ & Nilai $\mathbf{p H}$ \\
\hline $\mathrm{A}_{3}(750)$ & $2.59^{\mathrm{a}}$ \\
$\mathrm{A}_{1}(250)$ & $2.56^{\mathrm{a}}$ \\
$\mathrm{A}_{2}(500)$ & $2.56^{\mathrm{a}}$ \\
$\mathrm{A}_{0}(0)$ & $2.52^{\mathrm{b}}$
\end{tabular}

DMRT $0.05: 0.3298 \quad 0.034620 .03566$

Keterangan : Angka dengan huruf sama artinya tidak berbeda nyata pada DMRT $0.05 \%$.

Sementara itu, untuk perlakuan lama penyimpanan hari ke-0 $\left(L_{0}\right)$ mempunyai nilai $p H$ terendah yaitu 1.95 dan pada dasarnya berbeda dan tidak sama dengan perlakuan yang lainnya. Sedangkan perlakuan lama penyimpanan hari ke-60 $\left(\mathrm{L}_{4}\right)$ mempunyai nilai pH yang tinggi yaitu 3.38 yang juga berbeda dengan perlakuan lama penyimpanan yang lain. Artinya nilai $\mathrm{pH}$ dan total asam saling mempengaruhi, dimana ketika nilai $\mathrm{pH}$ mengalami peningkatan maka total asam akan mengalami penurunan begitupun sebaliknya (Nurman et al., 2018). Berdasarkan hal tersebut maka dengan menurunnya total asam selama penyimpanan nilai pH mengalami kenaikan. Hal ini disebabkan juga karena asam organik (asam askorbat, malat, sitrat dan folat) yang terkandung dalam buah pala melepaskan ion $\mathrm{H}^{+}$, seperti yang dijelaskan Sumanik, dkk (2017), bahwa nilai pH merupakan hasil dari penguraian asam organik, yang kenaikan nilai pHnya karena hasil pelepasan asam organik rantai karbon pendek, dan cenderung disebabkan oleh oksidasi asam organik, sehingga kandungan asam menjadi berkurang. 
Tabel 5. Nilai pH Selai Pala Pengaruh Perlakuan Waktu Penyimpanan

\begin{tabular}{cc}
\hline Waktu Penyimpanan (Hari) & Nilai pH \\
\hline$L_{4}(60)$ & $3.87 \mathrm{a}$ \\
$L_{3}(45)$ & $2.82 \mathrm{~b}$ \\
$\mathrm{~L}_{2}(30)$ & $2.57 \mathrm{c}$ \\
$\mathrm{L}_{1}(15)$ & $2.05 \mathrm{~d}$ \\
$\mathrm{~L}_{0}(0)$ & $1.95 \mathrm{e}$
\end{tabular}

DMRT $0.05: 0.03687 \quad 0.03871 \quad 0.03987 \quad 0.04068$

Keterangan : Angka dengan huruf sama artinya tidak berbeda nyata pada DMRT $0.05 \%$.

\section{Angka Lempeng Total (ALT)}

Pengujian terhadap Angka Lempeng Total atau ALT merupakan suatu prosedur pengujian yang dilakukan secara mikrobiologi untuk mengetahui total mikroorganisme yang terdapat dalam produk pangan seperti selai pala. Prinsip dari angka lempeng total yaitu apabila suatu sel mikroorganisme hidup ditumbuhkan atau ditanamkan dalam medium agar, maka sel mikroorganisme hidup akan beradaptasi, bertumbuh, berkembangbiak dan berbentuk koloni dan mudah diamati secara langsung. Pengujian Angka Lempeng Total (ALT) adalah salah satu contoh pengujian secara mikrobiologis yang sangat berperan penting guna menentukan keamanan produk yang dihasilkan. Pengujian Angka Lempeng.Total (ALT) pada penelitian ini dilakukan terhadap selai buah pala penyimpanan 60 hari (L4) dikarenakan secara visual selai buah pala penyimpanan $0,15,30,45$ hari memiliki tampilan yang bagus, baik warna, aroma maupun rasa.

Berdasarkan hasil penelitian Angka Lempeng Total (ALT) terhadap selai buah pala pada Tabel 6, menunjukkan bahwa perlakuan natrium benzoat mempunyai jumlah koloni atau sel mikroorganisme yang paling rendah bila dibandingkan dengan perlakuan tanpa natrium benzoat. Hal ini menunjukkan bahwa perkembangan koloni atau sel mikroorganisme tertekan dengan makin bertambahnya natrium benzoat yang digunakan pada selai pala, sehingga jumlah koloni atau sel mikroorganisme terendah pada penggunaan natrium benzoat $750 \mathrm{mg}$ $\left(A_{3}\right)$. Hal ini dijelaskan oleh Winarno (2004), bahwa efektifitas bahan pengawet anti mikroorganisme sangat ditentukan oleh konsentrasinya, artinya semakin besar konsentrasi pengawet yang digunakan maka semakin besar juga daya efektifitasnya. Winarno (2004), menambahkan pula bahwa keefektifan pengawet natrium benzoat dapat ditentukan berdasarkan kemampuan sel mikroorganisme beradaptasi terhadap molekul asam benzoat yang teroksidasi. Mudahnya oksidasi molekul asam benzoat ke dalam membran sel, disebabkan $\mathrm{pH}$ netral sel mikroorganisme sehingga asam benzoat akan mengalami proses oksidasi menghasilkan ion-ion $\mathrm{H}^{+}$. Hal inilah yang menyebabkan $\mathrm{pH}$ dalam sel mikroorganisme rendah dan dapat merusak organ-organ sel mikroorganisme tersebut, dengan demikian perkembangan mikroorganisme akan tertekan.

Angka Lempeng Total (ALT) yang dirata-ratakan dari jumlah koloni sel per masingmasing cawan duplo berkisar antara 25 sampai $41 \mathrm{CFU} / \mathrm{ml}$. Angka Lempeng Total terbesar, pada perlakuan konsentrasi natrium benzoat $0 \mathrm{mg}$, sedangkan Angka Lempeng Total terendah, pada perlakuan natrium benzoat $750 \mathrm{mg}$. Hal ini menunjukkan bahwa perkembangan koloni atau sel mikroorganisme tertekan dengan makin bertambahnya natrium benzoat yang digunakan pada selai pala, sehingga jumlah koloni atau sel mikroorganisme terendah pada penggunaan natrium benzoat $750 \mathrm{mg}\left(\mathrm{A}_{3}\right)$. Hal ini menurut Salfauqi, dkk (2018) bahwa natrium benzoat memiliki kemampuan dalam menekan laju pertumbuhan dan perkembangbiakkan mikroorganisme yang dipengaruhi oleh peningkatan pengawet natrium benzoat.

Selain itu juga, Menurut Siregar dkk., (2015) terhambatnya pertumbuhan mikroba pada perlakuan natrium benzoat disebabkan karena adanya gula yang ditambahkan dalam proses pembuatan selai pala (6 kg gula: $6 \mathrm{~kg}$ daging pala). Gula memiliki sifat osmosis (daya penyerapan air) sehingga air keluar dari bahan pangan dan kadar air bahan menjadi rendah dan dapat digunakan oleh mikroorganisme untuk pertumbuhannya. Hal ini disebabkan juga karena gula berperan sebagai pengawet yang guna mencegah pertumbuhan dan 
perkembangbiakan bakteri, khamir dan kapang, dengan mekanisme bahwa gula dapat mengakibatkan terjadinya dehidrasi sel mikroorganisme sehingga sel mikroorganisme mengalami proses plasmolisis sehingga terhambat perkembangbiakannya.

Ditambahkan pula oleh Winarno, (2004), bahwa asam yang ada secara alami pada buah seperti pala dapat menaikkan efektivitas natrium benzoat dalam mengawetkan produk sehingga apabila asam dalam jumlah yang cukup dapat mengakibatkan terjadinya denaturasi protein mikroba dan apabila asam dikombinasikan dengan panas akan sangat efektif dalam menekan laju pertumbuhan mikroba. Ditambahkan juga oleh Afriyanti, (2010), bahwa benzoat dan bentuk garamnya ini pada kondisi $\mathrm{pH}$ 2.5-4.0 dapat menghambat dan menekan laju pertumbuhan dan perkembangbiakan khamir dan bakteri, sejalan dengan hasil penelitian nilai $\mathrm{pH}$ selai pala pada penyimpanan hari ke 60 dengan natrium benzoat $750 \mathrm{mg}$ adalah 3.40 yang bersifat asam sehingga menghambat pertumbuhan khamir dan bakteri. Hal ini yang mengakibatkan sehingga selai pala yang disimpan hingga 60 hari dengan perlakuan natrium benzoat $750 \mathrm{mg}$ memiliki total mikroba terendah $25 \times 10^{-3}$, dan sesuai dengan SNI 01-37461995 syarat mutu selai buah yaitu maksimal $5.0 \times 10^{2}$.

Tabel 6. Angka Lempeng Total (ALT) Selai Pala

Pengaruh Perlakuan Natrium Benzoat dan Waktu Penyimpanan (60 hari)

\begin{tabular}{cc}
\hline $\begin{array}{c}\text { Perlakuan } \\
\text { (Natrium Benzoat dan Waktu } \\
\text { Penyimpanan) }\end{array}$ & $\begin{array}{c}\text { Rataan ALT } \\
\text { (CFU/ml) }\end{array}$ \\
\hline A0L4 (0 mg, 0 hari) & $41 \times 10^{-3}$ \\
A1 L4 (250 mg, 60 hari) & $38 \times 10^{-3}$ \\
A2L4 (500 mg, 60 hari) & $35 \times 10^{-3}$ \\
A3L4 (750 mg, 60 hari) & $25 \times 10^{-3}$ \\
\hline
\end{tabular}

\section{SIMPULAN}

Dapat disimpulkan bahwa penggunaan pengawet natrium benzoat dapat memperpanjang masa simpan selai buah pala sampai 60 hari penyimpanan, hal ini ditandai dengan jumlah koloni mikroorganisme terendah pada perlakuan natrium benzoat $750 \mathrm{mg}$ (25 $\times 10^{-3}$ ), serta mempengaruhi kandungan vitamin $\mathrm{C}$, kandungan total asam dan nilai pH yang terkandung dalam selai pala. Dari perlakuan konsentrasi natrium benzoat dan waktu penyimpanan yang diteliti diperoleh hasil selai pala terbaik yaitu perlakuan natrium benzoat $250 \mathrm{mg}$ dan 15 hari penyimpanan, dengan kandungan vitamin $\mathrm{C} 0.138 \mathrm{mg} / 100 \mathrm{~g}$ bahan, total asam $9.25 \mathrm{mg} / 100 \mathrm{~g}$ bahan, nilai $\mathrm{pH} 2.00$ dengan jumlah koloni mikroba $38 \times 10^{-3}$ dan sesuai dengan SNI 01-3746-1995 syarat mutu selai buah yaitu maksimal $5.0 \times 10^{2}$.

\section{DAFTAR PUSTAKA}

Afriyanti, L. (2010). Pengawet Makanan Alami dan Sintetis. Penerbit. Alfabeta: Bandung.

Farikha, Noor Ita., Choirul Anam dan Esti Widowati. (2013). Pengaruh Jenis dan Konsentrasi Bahan Penstabil Alami Terhadap Karakteristik Fisikokimia Sari bUah Naga Merah (Hylocerens polyrhizus) Selama Penyimpanan. Jurnal Teknosains Pangan. 2 (1), 30-38.

Mukaromah, Ummu., Sri Hetty Susetyorini dan Siti Aminah. (2010). Kadar Vitamin C, Mutu

Fisik, pH dan Mutu Organoleptik Sirup Rosella (Hibiscus sabdariffa, L) Berdasarkan Cara Ekstraksi. Jurnal Pangan dan Gizi. 1 (1), 43-51.

Naidu, K. A. (2003). Vitamin C in Human Health and Disease is Still a Mystery? An Overview. Nutrition Journal. 2 (7).

Oktoviana, Yanti., Stti Aminah dan Jamaluddin Sakung. (2012). Pengaruh Lama Penyimpanan dan Konsentrasi Natrium Benzoat Terhadap Kadar Vitamin C Cabai Merah (Capsicum annuum, L). Jurnal Akademia Kimia. 1 (4), 193-199. 
Polnaya, Febby., Sophia G. Sipahelut dan Sherly Lewerissa. (2009). Karakteristik Buah Pala Hasil Restrukturisasi Dengan Menggunakan Sistem Gel Alginat. Buletin Penelitian BIAM. V (54): 18-23.

Salfauqi, Nurman., Muhajir dan Virna Muhardina. (2018). Pengaruh Konsentrasi Natrium Benzoat dan Lama Penyimpanan Terhadap Mutu Minuman Sari Nenas (Ananas comosus, L). Jurnal Penelitian Pascapanen Pertanian. 15 (30), 253-361.

Sherlya., Nanda Yusriana dan Martunis. (2019). Pengaruh Penambahan Natrium Benzoat Terhadap Umur Simpan Selai Samahani Dengan Menggunakan Model Arthenius. Jurnal Ilmiah Mahasiswa Pertanian. 4 (4), 253-361.

Sipahelut, Sohia Grace dan Ivonne Telussa. (2011). Karakteristik Minyak Atsiri Dari Daging Buah Pala Melalui Beberapa Teknologi Proses. Jurnal Teknologi Hasil Pertanian. IV (2), 126-134.

Siregar, Roselda. (2008). Pengaruh Konsentrasi Natrium Benzoat dan Lama Penyimpanan Terhadap Mutu Marmalade Sirsak (Annona muricata, L) Skripsi Online. Departemen Teknologi Pertanian Fakultas Pertanian Universitas Sumatera Utara. Medan.

SNI (Standart Nasional Indonesia). (1995). Bahan Tambahan Pangan. Pusat Standarisasi Industri Departemen Perindustrian. 01-0222.1995.

Sudarmadji, S., Bambang Haryono., dan Suhardi. (2007). Analisa Bahan makanan dan Pertanian. Penerbit Liberty. Yogyakarta.

Sumanik, Rence Aurelia,. Pamela Mercy Papilaya dan Dominggus Rumahlatu. (2017). Pengaruh Konsentrasi Natrium Benzoat dan Lama Penyimpanan Terhadap Mutu Sari Gandaria (Bouea macrophylla, G) Berkarbonasi. Biopendix: Jurnal Biologi, Pendidikan dan Terapan. 4 (1), 22-28.

Sunanto, H. (1993). Budidaya Pala Komoditas Ekspor. Penerbit Kanisius: Yogyakarta.

Suprihatin. (2010). Teknologi Fermentasi. Penerbit UNESA Press: Surabaya.

Rorong, Johnly Alfreds dan Wiesye Fenny Wilar. (2019). Studi Tentang Aplikasi Zat Aditif Pada Makanan Yang Beredar Di Pasar Manado. Techno Science Journal, 1(2), 39-52.

Winarno, F.G. (2004). Keamanan Pangan Jilid 1. M-Brio Press. Bogor.

Zentimer, Suyetmi. (2007). Pengaruh Konsentrasi Natrium Benzoat dan Lama Penyimpanan Terhadap Mutu Minuman Sirsak (Annona muricata, L) Berkarbonasi. Skripsi Online. Departemen Teknologi Pertanian Fakultas Pertanian. Universitas Sumatera Utara, Medan. 